\title{
An Assessment of Electronics Tax Register System Implementation and Challenges, Case of Nekemt Town Value Added Tax
}

\author{
HASHIM TUNE SADO (MSc) \\ Wollega University, College of Business and Economics, Department of Accounting and Finance \\ P.O. Box: 395, Nekemte, Ethiopia.
}

\author{
Acronym and abbreviation \\ CIF: cost, insurance and freight \\ ERCA: Ethiopia Revenue and Custom Authority \\ ETRM: Electronics tax register machine \\ ETRs: Electronics tax register system \\ FIRA: Federal Inland Revenue authority \\ GAO: Government account office \\ GDP: Growth domestic product: \\ IMF: International Monitory Fund \\ IT: information technology \\ ITAS: integrated tax administration systems \\ OECD: Organization for Economic Co-operation and Development \\ SPSS: Statistical Package for Social Scientists \\ SSA: Sub-Saharan African \\ SSN: Social Security Number \\ TIN: Tax Identification number \\ TOT: Turn over tax \\ VAT: Value added tax
}

\begin{abstract}
The main purpose of this study is to assess Electronics tax register system implementation challenges in process of Value added tax in Nekemt town. In order to maintain the desired objectives descriptive survey research is designed for the study. Using systematic sampling method 226 tax payers were selected from the total population of 521 and purposive sampling were used to take 8 experts from ERCA office. The main data of this study was both primary and secondary data. The Statistical Package for Social Sciences (SPSS) version 20 was used to analyze data using descriptive statistics like percentage and frequencies of the variables, and arithmetic mean. The results reveal that, there are major challenges which are confronted by VAT payers for using ETRs such as; incur additional cost (machine purchase, maintenance cost) no adequate training regarding ETRs. The paper suggests that attention should be given to training regarding ETRs and Introduce ETR machine that is not expensive to tax payers.
\end{abstract}

Keywords: Value added tax, Electronics tax register machine

DOI: $10.7176 / \mathrm{EJBM} / 12-10-03$

Publication date: April $30^{\text {th }} 2020$

\section{Background of the study}

A tax "is not a voluntary payment or donation, but an enforced contribution, exacted pursuant to legislative authority" and is "any contribution imposed by government whether under the name of toll, tribute, tallage, gabel, impost, duty, custom, excise, subsidy, aid, supply, or other name." (Black's Law Dictionary, 1979)

The introduction of VAT simplifies substantial improvement in overall tax administration, and indeed adoption of the VAT is often seen as an opportunity for overall tax administration and modernization, however, has occasionally disrupted the functioning of an existing administration because of inadequate preparation, lack of uniformity in application, lack of awareness by the side of the Taxpayer, application contrary to the law and problems related with institutional capacity. (Bizualem,2013)

The modernization of the tax collection system using ETRs is expected to assist traders in such ways as to save their time in perusing of records and reduction in tax preparation costs that used to be paid to tax agencies. Tax refund claims can also be easily handled and as result reduces costs of businesses. (IMF, 2005).

A number of countries, particularly in Africa, have introduced a compulsory use of electronic cash registers (ECRs) to facilitate turnover verification. Ethiopia also began the use of Cash Register Machine. Since the main aim of the introduction of Cash Register Machine in Ethiopia is to increase valid trust among the tax payers and 
ERCA also to change the manual paper work to a systematic computerized application work. In Ethiopia, a few number of studies have been done on Electronics Tax Register machine they focused on impact of Electronics machine on VAT compliance, they conclude that implementation of ETRs have a cause to happens a tremendous change on the VAT income So, the cash register machine has a positive impact on VAT income of the country (YalemTesfa, 2011; Abdu and Zemenu, 2015)

But implementation of ETRs challenges related issues are still questions to the government, policy makers and for concerned experts. Still in study area there is no such well-organized and documented research result, which can expose challenge of ETRs implementation.

In general this research tries to answer the following question:

$\checkmark$ How business communities perceive implementation of ETRs?

$\checkmark$ What are major challenges faced by ETRs implementer?

$\checkmark \quad$ Is implementation of ETRs increase or decrease annual Gross Revenue in nekemt town?

\section{Objective of the study}

The General objective of the study is to assess the Electronic tax Registration system implementation challenges in process of Value added tax in Nekemt Town.

\section{Specific objective}

$>$ To evaluate the perception of VAT payers (business community) towards ETRs

$>$ To identify the major challenges confronted by Electronics Tax Register implementers (Government authority).

$>$ To investigate annual gross revenue of Nekemt town before and after introduction of ETRs The concepts of tax and tax system

A tax may be defined as a "pecuniary burden laid upon individuals or property owners to support the government. A payment exacted by legislative authority. Tax is a payment extracted by government from people and organizations to fund public expenditures without -rendering proportionate benefits by the use of law.

Tax is a liability imposed upon the taxpayers assesses who may be individuals, group of individuals or other legal entities. It is a liability to an amount on account of the fact that tax assesses has income of a minimum amount and quid-pro quo- means one thing exchanged for another, equivalent in value (Lamesa, 2012). Taxation is a system of raising money to finance government. All governments require payment of money- taxes-from people. Governments use tax revenues to pay soldiers and police, to build dams and roads, to operate schools and hospitals, to provided food for the poor and medical care to the elderly, and for hundreds of other purposes.

The purpose of taxation includes several other goals apart from raising revenue. Example of those other goals are: influencing the rate of economic growth, encouraging full employment, combating inflation, favoring small enterprises and redistributing of national income on more equal basis and taxes raise money to spend on armies, roads, schools and hospitals, and on more indirect government functions like market regulation or legal systems.. Ross L. (2007)

\section{Overview of taxation in Ethiopia}

In Ethiopia there are two types of tax. These are Direct and Indirect tax. The principal taxes currently in place are profit tax; turn over tax (TOT), value-added tax (VAT), excise tax, customs duty, and income tax from employment and other taxes include corporate tax, dividend income tax, royalties and stamp duties. (Negarit Gazeta)

\section{VAT (Value Added Tax):}

Proclamation No.285/2002 stated that a few transactions are zero rated but these are very limited: exports; international transport; supply of gold to the National Bank; or sale of a business as a going concern. All other goods and services are liable to VAT at a rate of 15 percent.

The value added tax (VAT) is simply a multistage sales tax that exempts the purchase of intermediate goods and services from the tax base. It is designed to be paid on the value added which is the difference between the value of sales and value of purchase at the point of transaction throughout the production and distribution chain. Any producer owes tax only in the value added; in practice this means that the producer will have refund for VAT paid on all the purchases or inputs. (Haila Mariam, 2011)

According to Wollela (2008),in Ethiopia the major activities in VAT administration are identification and registration of taxpayers, processing returns, controlling collections, making refunds, auditing taxpayers, investigation of tax fraud and evasion , and leaving penalties, Perhaps peripherally, VAT administration is also concerned with issues of who should administer the tax, what organizational setup to use and what resources are available. Tax administration impacts countries economy other directly or indirectly. 


\section{VAT Development in Ethiopia}

The Ethiopian government has introduced VAT as part of the overall tax reform program. In Ethiopia VAT was first introduced in January 1st, 2003 to replace the sales and excise taxes as proclamation No. 68/1993 (as amended). Thus, VAT applies to firms with a turnover of more than Birr 500,000. Although companies complained, the new tax simply replaced the former sales tax and so added little to companies (Christopher 2006.)

\section{VAT implementation challenges}

Not all countries are ready for the VAT, and for those that are, there is no universal approach to introducing this tax instrument. According to, (Tadros, 2009) Challenges that arise in introducing a VAT system commonly relate to three issues: Weak administrative procedures for a complex process, the revenue authority honoring its side of the deal, misrepresentation on the part of the firms applying for refunds.

\section{Using modern Technology for improvement of tax system}

The task of tax administrations is to collect the right amount of tax from the right taxpayer at the right time, but their interim strategic objectives can include achieving uniformity in applying tax laws providing quality taxpayer service, improving compliance, or other. Each of these objectives calls for a different IT Intervention. A cash register is an electronic tool used to calculate and record sales transactions with a cash drawer that will be used to store cash. This machine will automatically print receipt after a certain amount and the money transactions compared to the manual transaction of sales. (http://www.wikihow.com/Use-a-Cash-Register).

\section{The Sales Register Machines Directive No 46/2007}

The Directive is issued by the Minister of Revenue pursuant to the power given by Article 22 of the council of Ministers Regulations to provide for the obligatory use of sales Register machines No 139/2007. This Directive cited as the "Directive issued to provide for the use of sales register machines No 46 /2007".

The Ethiopia Revenue and Custom Authority (ERCA) adopted the Electronic Tax Register (ETRs) Automated system for Customers data management. The use of sales register machine in Ethiopia across the country keeps on increasing. (Hamdu and Zinash 2014)

\section{Challenges related to using the Automated Tax collection system}

Two areas where technology is commonly used to automate VAT compliance processes are: Automated determination, calculation and recording of transactional taxes (Determination processes) and Automated production of VAT returns (compliance processes).

According to Lumumba Omweri Martin, (2010) the introduction of ETR has assisted in cutting costs that the business used to incur in processing VAT. It was found that ETRs have enhanced the revenue collection resulting from sound sales and stock audits. And faced challenges while implementing ETRs such as; the cost and classification of the businesses which need to use ETRs: ETRs are expensive, cost to be paid in installments; ETRs should be compatible with computers in business premises.

According to Abdu and Zemenu,(2015) use of ETRMs among VAT registered tax payers is correlated with high level of tax compliance attitude. The tax morale of tax payers, the fine and penalties of tax law and probability of Audit have positive and significant impact on understand on VAT compliance.

Complying with the system paying taxes costs taxpayers money above and beyond the actual tax bill. These costs include the money that people spend on accountants, tax lawyers, and tax preparers, as well as the value of taxpayers' time spend filling out tax returns and keeping records. For a business, the compliance costs include the costs of collecting, remitting, and accounting for tax on the products or profits of the business, and on the wages and salaries of its employees. Compliance costs for businesses also include the costs of acquiring the knowledge to enable this work to be done, including knowledge of their legal obligations and penalties. (Sandford, 1989). 


\section{Conceptual frame work}

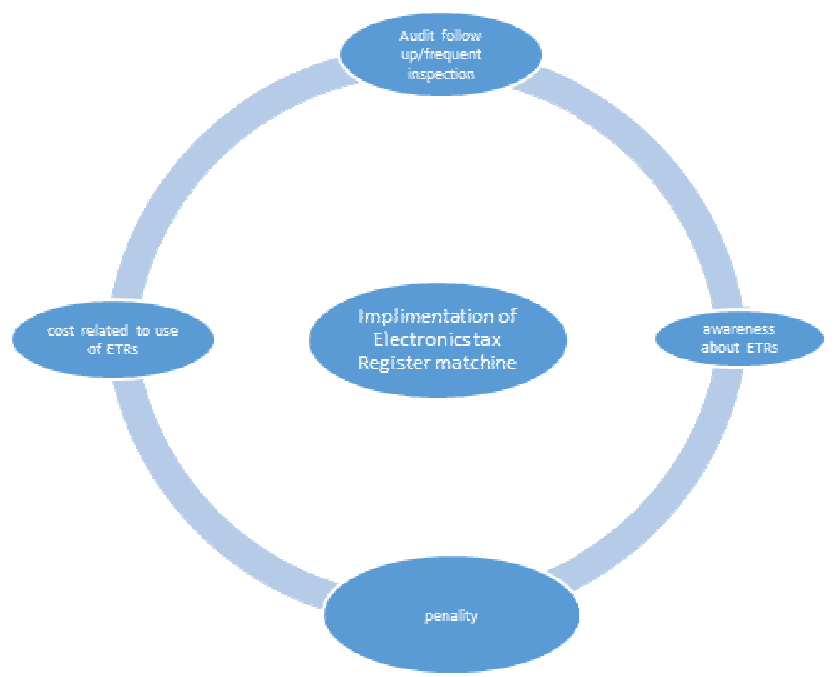

Source: researcher develops own conceptual framework

\section{Data Types and Source}

This study was employed both primary and secondary data sources. The primary data was collected from selected VAT payers and tax authority through questionnaire, Interview and focus group discussion. Secondary data was collected from:-Nekemte town VAT collection trends, six years revenue reports, from 2011/012 to 2016/017, East Wollega Zone revenue and tax authority sector data base, Various books, journals, articles and different web site materials related to study area.

\section{Sampling and survey design}

According to East Wollega Zone tax authority office report, on 2017, there were 521 VAT registered tax payers residence in the Nekemt town. Since there is a different sector with different business categories, the method used for case study was mainly stratified sampling followed by systematic sampling as population of the study is heterogeneous and to give equal chance for all business sectors respectively and purposive sampling were used to select tax offecials from Nekemt town revenue authority. In this study the researcher was used the sample size determination formula, which is developed by Glen as cited in Yamane (1967) to determine the sample size for the study. This is under confidence level of $95 \%$ and level of precision $\pm 5 \%$

$n=\frac{N}{(1+N(e) 2}=\frac{521}{(1+521(0.05) 2}=\frac{521}{2.3}=226$

Where:

$\mathrm{n}=$ sample size,

$\mathrm{N}=$ population size,

confidence level of $95 \%$

$\mathrm{e}=$ the level of precision

Level of precision $5 \%$

Hence, in order to get 226 sample size out of targeted population, sample proportion to size formal applied as follows;

Table 3.1: Summary of total population of each category and its sample size

\begin{tabular}{|l|c|c|c|c|}
\hline Target group & Symbol of category & Population & Sample & $\%$ (percentage) \\
\hline \multirow{2}{*}{$\begin{array}{l}\text { VAT registered } \\
\text { traders }\end{array}$} & Services sector & 203 & 88 & $38.94 \%$ \\
\hline & Goods Sector & 318 & 138 & $61.06 \%$ \\
\hline \multicolumn{2}{|c|}{ Total } & 521 & 226 & 100 \\
\hline
\end{tabular}

Source: Own computation 2018 
RESULT AND DISCUSSION

Table 4.1 tax payers response on registered for VAT and use of ETRs

\begin{tabular}{|c|c|c|c|}
\hline Item & Frequency & Percentage & Mean \\
\hline \multicolumn{4}{|l|}{ 1. When your organization registered for VAT } \\
\hline This year & 44 & 19.4 & \\
\hline Two to Three year & 58 & 25.7 & \\
\hline Above three year & 124 & 54.9 & \\
\hline \multicolumn{4}{|l|}{ 2. When your organization started using ETRs } \\
\hline This year & 89 & 39.4 & \\
\hline Two to Three year & 68 & 30 & \\
\hline Above three year & 58 & 25.7 & \\
\hline Not use & 11 & 4.9 & \\
\hline
\end{tabular}

Source: Own survey 2018

As depicted on the above table 4.1 item $1,44.9 \%$ of respondent were indicated that they were registered for VAT more than three years ago, $25.7 \%$ of respondent indicated that they registered two to three years ago, $19.5 \%$ of respondent were responded that they were registered this year. Based on the analysis, it is concluded that in the study area most of VAT registered business organization were registered to collect VAT three and above years ago. It's possible to conclude that most of the respondents have experience on VAT collection.

concerning the length of time the respondents were asked to give the time when they were started to use or collect VAT through Electronics tax register machine, 39.4\% of respondent were started to using this year, 30\% of respondent were started two to three years ago and $25.7 \%$ of respondent were started using before three years ago and $4.9 \%$ of the respondent still do not start using the system they are on waiting list. So, it is possible to conclude that, most of the respondent start the use of Electronics tax register machine for period of less than three years this reveal that the use of ETRs is at its infant stage in the study area.

Perception of output VAT payers (business community) towards ETRs

4.2 respondents view about ETRs

\begin{tabular}{|c|c|c|c|}
\hline Item & Frequency & Percentage & Mean \\
\hline \multicolumn{4}{|l|}{ 1. Information source about ETR for first time } \\
\hline Tax authority (Government) & 69 & 30.6 & \\
\hline Media & 109 & 48.2 & \\
\hline Other & 48 & 21.2 & \\
\hline \multicolumn{4}{|c|}{ 2. Whether they informed by authority about ETRs before registered } \\
\hline Yes & 76 & 33.6 & \\
\hline No & 97 & 42.9 & \\
\hline Informed but not understand & 53 & 23.5 & \\
\hline \multicolumn{4}{|l|}{ 3. Under which condition they registered to use ETRs } \\
\hline After knowing about Electronics tax register & 21 & 9.3 & \\
\hline After survey made for registration & 44 & 19.5 & \\
\hline No any condition but call to registration & 57 & 25.2 & \\
\hline Authority forced me & 104 & 46.0 & \\
\hline \multicolumn{4}{|c|}{ 4. Adequate Training was given about Electronics tax register system } \\
\hline Yes & 72 & 31.9 & \\
\hline No & 154 & 68.1 & \\
\hline \multicolumn{4}{|c|}{ 5. Why they registered to use Electronics tax register system } \\
\hline personal interest & 5 & 2.2 & \\
\hline Obligation from authority & 147 & 65.0 & \\
\hline To control sales & 74 & 32.7 & \\
\hline
\end{tabular}

Source: Own Survey 2018

In putting idea about The Electronics tax Register system in the mind of business tax payers before they start to use is, one of the method make smoothing the system implementation. The information as to how the VAT payers heard about the beginning of the Electronics tax register system of taxation in their administrative zones were different. As indicated in Table 4.2 above, concerning information access about ETRs 109(48.2\%) of respondent confirmed that they heard about ETRs from different media, while $69(30.5 \%)$ of them were have attended government training program regarding the implementation and guidelines of the VAT system by concerned government authorities. On the other hand, $48(21.2 \%)$ of them responded that they have heard either from media or training and just learned from their friends but not give attention. The data shows that the government authorities were perform less to create the awareness on ETR system to potential VAT Payers 
before the implementation of the system into practice.

As displayed in table 4.2 above, whether VAT payers informed by authority about ETRs before registered to Use $97(42.9 \%)$ of respondents responded that they are not informed about Electronics tax register system by tax authority before registration, 76 (33.6\%) responded that they heard about it before registration and 53(23.5\%) of respondent report that they heard to use but couldn't understand. So, researcher concludes that, most VAT registered group forced to use than understanding advantage of the system. On the other hand, telling doesn't create understanding among all, but taking time to help them understand and knowhow and long run advantage of tax payment by using ETRs as well. Lack of pre-information and not having good understanding about the system and advantage of using the system payment among respective business makes weaken the income of the town at study area and that of country at large.

As shown in table 4.2 items 4 , most respondent have not took adequate training on the usage of tax register machine and advantage of the system. This can possible create difference in knowledge about system among the taxpayers. This means there created great difference of motivation towards paying expected amount as revenue to the town tax collecting sector authority. It is also the condition that made most taxpayers to use their duty forceful than based on interest understanding the ever advantage of collecting VAT by using new technology and increasing revenue for country development at large. This showed there was gap among taxpayers on the level of adequate training given to them.

It is not only Government who get advantage from implementation of the Electronics tax registration system but also the business organization that use the system. As per interview result from Nekemt Town tax Authority office employee, simply to know exact amount of their revenue and to save their business. for example, VAT registered tax payers who have more than one business center may have many ETR machine that connected to central computer and simply control their daily business and at the end of month unlike manual that take time for reporting they simply order the machine to display report of the month. Additionally as shown on table 4.2 item 5, 65\% of respondents reported that they were obliged to undergo Electronics tax registration system for their business by authority but not voluntary registered. So most taxpayers didn't know benefit of using the system whiles some of them know benefit of being using the system. That means a few number of respondents have had personal interest to register for using the system. Even if many pay the amount expected of them by using the system, they have been paying using it with no interest. This on the other hand brought misunderstanding among taxpayers and tax collectors as there is no sustainability on forcing people to do their own duty to pay for authority.

In relation to creating healthy and correct perceptions on the payment of VAT by using new technology that is Electronics tax register system, it is very understandable that the first step is creating the awareness of the importance using the system for those who are eligible to pay VAT. Most of the respondents who do not support of being registered for using Electronics tax register system were also asked to give their reasons why they do not support the system and they have forwarded different reasons which can be summarized into the following points:-

* Since, the machine is sensitive once it is made error there is penalty from authority and other type of machine is directly connected to the power, so that if there is no electric power we can't use the machine and there also penalty why we do not use the system. So that penalty is increasing after we using the system and they also said that there are additional cost to our business for using the system.

\section{Method of VAT settlement when VAT payers pay VAT collected}

It is understandable that the degree of success in settling VAT payments depends on the sophistication of the mode of payment. As it's known, the more the modern the VAT paying and receipts registration system is, the more is the smooth and tamely settlement of the payment is expected to be. The data survey on this regard showed that out of the sampled 226 VAT paying businesses, 215(95\%) of them are using cash registration machine while the rest, $11(5 \%)$ of them use the manual cash receipt record papers. This shows that most VAT payer business is using the Electronics tax register system during VAT settlement so that the VAT system will be effective in minimizing VAT evasions.

But, not every VAT payer believes he/she is in a position to incorporate the modern system due to different reasons, those who do not settle their VAT by using the system further asked the reason and they respond that some of them revealed that they don't have the ability to afford to purchase the VAT registration machine and most of them are on waiting list to purchase the machine.

The main sources of additional costs identified were: cost related to salary of machine operator, the cost of machine purchase, installation of machine, ETRs maintenance cost, purchase of stationeries and cost of annual machine checkup. 


\section{Amount of VAT collected by VAT payers increase after implementation of ETRs}

Figure 4.1

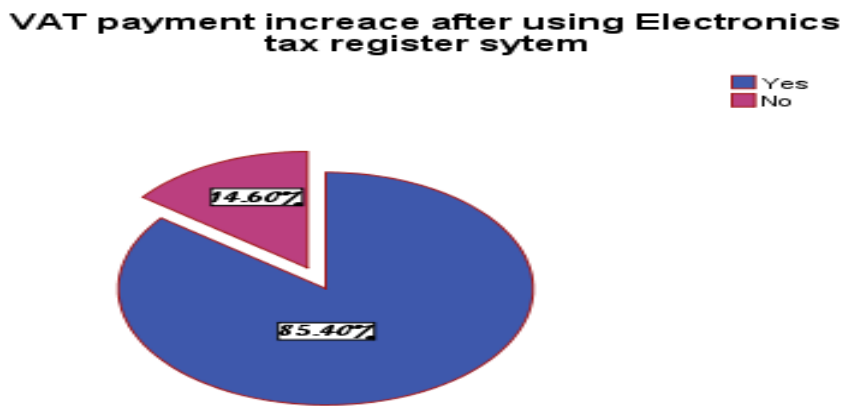

Source: Own survey 2018

It is well known that government introduce new technology for collecting right amount of tax and to reduce tax evasion. As it shown from Figure 4.1, 85.4\% of respondent responded that their VAT payment were increasing after they start using the system and remaining $14.60 \%$ respond that their VAT payment is the same before and after they use the system. In fact it concluded that the VAT payment to the authority is increasing and it increase revenue of the town and government at large.

Table 4:3 respondent's view on penalty and audit follow up

\begin{tabular}{|c|c|c|}
\hline Item & Frequency & Percentage \\
\hline 1. there is lack of transparency on imposing penalty & & \\
\hline Yes & 169 & 74.8 \\
\hline No & 57 & 25.2 \\
\hline $\begin{array}{l}\text { 2. Is there audit follow up or inspection after introduction of Electronics } \\
\text { tax register system }\end{array}$ & & \\
\hline Yes & 49 & 21.7 \\
\hline No & 61 & 27.0 \\
\hline Rare & 116 & 51.3 \\
\hline $\begin{array}{l}\text { 3. Whether they faced technical problem after they started using } \\
\text { Electronics register system }\end{array}$ & & \\
\hline Yes & 154 & 68.1 \\
\hline No & 72 & 31.9 \\
\hline $\begin{array}{l}\text { 4. supplier of Electronics tax register system maintain within short } \\
\text { period of time when it damaged }\end{array}$ & & \\
\hline Yes & 97 & 42.9 \\
\hline No & 129 & 51.3 \\
\hline
\end{tabular}

Source: Own survey 2018

It is well known that penalty regarding tax related issue is very serious; in Ethiopia the VAT legislation proclaims that taxpayers fail to fulfill the pre-conditions of VAT are chargeable with penalties ranging from financial penalties to imprisonment. For instance, although the legislation in general stipulates a penalty of 5 percent of the amount of VAT unreported/underpaid, in practice (according to the outcomes of the in-depth interviews with tax officials) a late filing penalty of ETB 1,000 for each accounting period the tax remained underreported is imposed. But the question is that whether the tax payers are known types of these penalties and equally punished for common mistakes. in order to know this the respondent were asked whether there is transparency on imposing penalty ,according to data summarized in Table $4.3,169(74.8 \%)$ of respondent reply that there is no transparency in imposing penalty, and $57(25.2 \%)$ of respondent respond that there is transparency in imposing penalty. From this it is concluded that there is no trust between tax authority and tax payers, In addition, the lack of consistency and transparency in administratively imposing the penalty may open a room for corruption and fraud.

Electronics register machine is sensitive machine and it needs special care from users and supplier of the machine and the Authority should follow up the users of machine if it defective or not functioning as prescribed by the Regulation. As per part three of Directive No 46/2007 one of the obligations of the service center who made contract with supplier of machine is to make inspection to users of the machine. So in order to know whether there is Audit or inspection is there the respondents were asked, and according to Table 4.3 above, out of sample 226 only $49(21.7 \%)$ of respondent said there is inspection or follow up after system implementation 
and remaining $116(51.3 \%), 61(27 \%)$ of respondent respond that there is rare inspection and there is no inspection respectively. it is possible to conclude that there were rare inspection from service center and tax revenue authority, which result more challenges for implementation of the system and difficult to achieve desired goal accordingly.

Like any other machine ETRs is subjected to breakdown, as summarized in table 4.3 above respondent were asked to indicate whether they encountered problem with the machine, 154(68.1\%) of respondent reported that they faced problem during using the machine and $72(31.9 \%)$ of respondent indicated that they do not encountered problem. This is truly show that the machine is sensitive to problem or it confirm that the users of machine were had no knowledge regarding usage of the system.

As indicated above in table 4.3, respondent were asked to give their thinking whether the supplier of ETR machine maintain within short period of time when the machine is damaged or encountered with other problem, as the result of data survey showed that $116(51.3 \%)$ of respondent reply that the supplier of ETR machine didn't response within short period of time when machine is damaged or other technical problem occurred. It's possible to conclude that, supplier of ETR machine had not solved immediately the problem faced with users ETR machine. But it is predetermined by the law, as per Regulation (No 46/99) it is responsibility of ETR machine users to report any breakdown of their ETR machine to Authority, since such breakdowns might lead to failure to file returns, failure to pay correct taxes, tax evasion activities, non-payment of duty on imported goods undisclosed payments to employees, unethical conduct by ERCA officers and /or taxpayers, which amount to corruption. After reporting the breakdowns, it is the responsibility of ERCA to take action. And supplier of machine should give response or maintain machine within 48hrs. This has indicated that the ETRs suppliers didn't give adequate service as they were required to be stated in the legislation. Furthermore respondent also asked whether they satisfied with service given by supplier of ETR machine, $56.2 \%$ of respondent responded that they were not satisfied with service provided by supplier.

Table 4.4, Cash register machine experts' opinion about ETRs Implementation challenges

The cash register machine experts were asked different questions with regards to a cash register machine implementation challenges from different aspects. The respondents were asked whether they encountered problem during implementation of the system. 8 experts were used in the analysis.

\section{Response Scale}

\begin{tabular}{|l|l|l|l|l|}
\hline Strongly Disagree & Disagree & Neutral & Agree & Strongly Agree \\
\hline
\end{tabular}

\begin{tabular}{|c|c|c|c|c|c|c|}
\hline No. & Item & 1 & 2 & 3 & 4 & 5 \\
\hline 1 & Using ETRs reduce tax evasion or fraud & - & - & $\begin{array}{ll}1 \\
12.5 \%\end{array}$ & $\begin{array}{ll}4 \\
50 \%\end{array}$ & $\begin{array}{ll}3 \\
37.5 \%\end{array}$ \\
\hline 2 & Adequate training given for ETRs Expert & $\begin{array}{l}2 \\
25 \% \\
\end{array}$ & $\begin{array}{l}3 \\
37.5 \% \\
\end{array}$ & $\begin{array}{l}1 \\
12.5 \% \\
\end{array}$ & $\begin{array}{l}2 \\
25 \% \\
\end{array}$ & - \\
\hline 3 & All VAT registered business are using ETR system & $\begin{array}{l}5 \\
62.5 \% \\
\end{array}$ & $\begin{array}{l}1 \\
12.5 \%\end{array}$ & $\begin{array}{l}2 \\
25 \% \\
\end{array}$ & - & - \\
\hline 4 & $\begin{array}{l}\text { Your office is effective in auditing, inspection and } \\
\text { enforcement for use cash register system. }\end{array}$ & $\begin{array}{l}4 \\
50 \%\end{array}$ & - & $\begin{array}{ll}1 \\
12.5 \%\end{array}$ & $\begin{array}{l}3 \\
37.5 \%\end{array}$ & - \\
\hline 5 & $\begin{array}{l}\text { Taxpayers highly know about Electronics tax register } \\
\text { machine }\end{array}$ & $\begin{array}{l}4 \\
50 \% \\
\end{array}$ & $\begin{array}{l}1 \\
12.5 \% \\
\end{array}$ & $\begin{array}{l}2 \\
25 \% \\
\end{array}$ & $\begin{array}{l}1 \\
12.5 \% \\
\end{array}$ & - \\
\hline 6 & $\begin{array}{l}\text { implementation of ETRs improve tax report of VAT } \\
\text { register tax payers }\end{array}$ & $\begin{array}{ll}1 \\
12.5 \% \\
\end{array}$ & - & $\begin{array}{ll}1 \\
12.5 \% \\
\end{array}$ & $\begin{array}{ll}6 \\
75 \% \\
\end{array}$ & - \\
\hline 7 & $\begin{array}{l}\text { tax payers does not have good perception for tax audit or } \\
\text { inspection follow up system }\end{array}$ & - & - & $\begin{array}{l}1 \\
12.5 \% \\
\end{array}$ & $\begin{array}{l}7 \\
87.5 \% \\
\end{array}$ & - \\
\hline 8 & $\begin{array}{l}\text { Encountered VAT payers using un authorized as well as } \\
\text { un register VAT machine }\end{array}$ & - & $\begin{array}{l}6 \\
75 \%\end{array}$ & - & $\begin{array}{l}2 \\
25 \% \\
\end{array}$ & - \\
\hline
\end{tabular}

It is tax evasion that decrease Revenue of Government that is collected from tax .Tax evasion often entails taxpayers deliberately misrepresenting the true state of their affairs to the tax authorities to reduce their tax liability and includes dishonest tax reporting, such as declaring less income, profits or gains than the amounts actually earned, or overstating deductions. As depicted on the above table 4.4 the use of cash register machine can help in reducing tax evasion or fraud and facilitates a VAT collection process, and as per interview result since the machine is computerized it record daily transaction of tax payers and it connected to central computer for recording on respecting TIN of each tax payers and at the end of the month, amount of VAT collected by each VAT payers taken from their respective TIN.

Without understanding about the system it is difficult for them for implementation and makes inspection to tax payer for enforcement of using the system. The tax authority is weak in providing training for the experts 
before implementation of the system, this makes difficult follow up and inspection of the system.

There are VAT payers which are not using the system. This may create discrimination and make fear of competition between system users and those who didn't use the system. As per interview result, one of the factors challenges Authority to reach the machine to all potential VAT payers is there is only sole supplier and it is difficult for Authority to give adequate training at one's for all VAT payers, this may open door for corruption and decrease revenues of government and even those having the machine did not record all sales in the machine which affects the amount of net VAT payable to tax authority.

Concerning audit follow up and inspection the response shows that, even if it is not at all, there is follow up directly or indirectly whether the users of ETRs using the machine regularly. Directly by making Audit the VAT payers and there is door to door follow up by making intelligence checking suddenly if customers of VAT payers were buy goods without ETRs receipt given to them and make penalty those who didn't use the system. But it is difficult for reaching all VAT payers business organization by existing human powers of Authority office.

One of the purposes of modernization of tax collection system is to get clear report from tax payers at the end of the month. As per interview result when comparing the manual taxpaying system with new automation system one: manual filing is the most traditional and popular method of filing and paying taxes. During the taxfiling and payment period, taxpayers perform complex calculations and fill out a standard printed form either by hand or typewriter. The tax return and related documentation are submitted to the tax Authority over the counter or by postal mail. The tax agency uses either manual data entry or image processing to enter the tax return data into its computers. When using the manual filing method, taxpayers need to understand the individual income tax laws, and the tax return is subject to errors through writing and/or calculations. For the tax collection department, manual filing represents a tedious task, where they have to enter the taxpayers' data into their computer system both quickly and accurately. But in ETRs it is simple for tax payers only printing from the system and submits their report to Authority at the end of the month. So that it is concluded from survey data report that VAT payers report at the end of the month were improved after implementation of the system.

Additionally, business people didn't have good perception towards implementation of ETRs machine and Audit follow up or inspection made by authority. This is due to auditing or inspection involves with tax penalty those who didn't use the system regularly. For example, unless the machine is on the maintenance those who sale without the machine or without receipt must penalized until fifty thousand birr. But Auditing and inspection is beyond that it is follow up the system and to solve problem that the tax payers encountered during the use of machine.

Collecting of VAT with illegal or UN authorized machine by a business organization is the practice made to evade government income. This is out of the essence of the proclamation and challenging the implementation of ETRs. This kind of practice is considered as tax evasion, which is criminal offence under Ethiopian law that is subject for punishment that is not less than one year and not greater than two years prisoned as prescribed by

Directive No 46/2007. This practice is not that much happened in the study area.

Change of VAT returns after implementation of ETRS

\begin{tabular}{|l|l|l|l|l|}
\hline Year & No. of registered VAT payers & Amount of VAT collected & Increased by & Change in percent \\
\hline $2003(2011)$ & 81 & $1,926,681.58$ & - & - \\
\hline $2004(2012)$ & 175 & $7,817,654.17$ & $5,890,972.59$ & $305 \%$ \\
\hline $2005(2013)$ & 307 & $22,685,568.66$ & $20,758,887.08$ & $1077 \%$ \\
\hline $2006(2014)$ & 365 & $31,766,582.67$ & $29,839,901.09$ & $1548 \%$ \\
\hline $2007(2015)$ & 406 & $37,370,223.60$ & $35,736,489.72$ & $1854 \%$ \\
\hline $2008(2016)$ & 410 & $36,663,171.30$ & $34,736,489.72$ & $1803 \%$ \\
\hline $2009(2017)$ & 521 & $33,163,147.91$ & $31,236,466.33$ & $1621 \%$ \\
\hline
\end{tabular}

The researcher gathered data from Revenue authority of Nekemt Town and Sector data from East Wollega Zone Revenues authority to measure the change of the government income and to compare gross of Revenues before and after implementation of ETRs. As data collected shows during the pre- ETRs period the amount of Tax revenue collected by business firms increased from 1,926,681.58 ETB in 2011 to 7,817,654.17 ETB in 2012, indicating that there is increase in revenues collection. The trend also continued to rise during the post- ETRs period 22,685,568.66 ETB in 2013 to 31,766,582.67 in 2014 and reached its highest level 37,370,223.60 in 2015 and then decline to $36,663,171.30,33,163,147.91$ in the year 2016 and 2017 respectively which is because of miss utilization of the machine and political crisis during these years. When I compared pre-ETRs implementation with post, it shows that there is great change in revenue collection after introduction of ETRs. As per interview made with Employees of Revenues authority the increasing trend in indirect tax is mostly due to the massive introduction of ETRs and increase in the number of VAT registered tax payers. Throughout the process of development, the amount of direct tax, indirect tax, domestic tax, and total tax revenue have shown a trend to rise, as the revenue authority began undertaking improved mechanisms of tax revenue collection mainly the introduction of ETRs. 


\section{Conclusion}

This study was conducted to assess the Electronics tax Register system implementation challenges in Nekemt town. Data has been collected from VAT registered tax payers (Business community) and Employees of Nekemt town tax authority office to assess their perception towards ETRs and point out the major problem in its implementation. Based on the results of the analysis and discussions of the data, the following conclusive evidences can be derived:

Lack of pre-information and not having good understanding about the ETRs and advantage of Using the system among respective business makers weaken the income of the town at study area and that of country at large.

It is high responsibility of tax officials to expand the network of accountability and responsibility and other principles to govern tax payment system in a transparent ways in advance. These uncover all problems in tax payment system so that all can work together for the betterment of ETRs implementation in effective and efficient ways among all at all required level if it was survey based. Most taxpayers have had no good background about ETRs but registered for using in fear of the policy set which imposed on them with no mutual understanding.

In the voucher (manual) system the most headache event in ERCA was the Tax evasion. Since the customer and the seller agreed they make the transaction without a receipt. Even in Cash Register Machine system tax evasion is one of the problems that ERCA couldn't control it. The result shows that; Even if it is not fully controlled, tax evasion decreases after the introduction of Cash Register Machine. This might be because of ETRs is connected to central computer and record daily sale of individual VAT registered business on respective of their TIN. When VAT registered tax payers settled amount of VAT they collect, it is compared with amount of VAT recorded on central computer as per their TIN. This is result of introduction of ETRs.

It is true that a few respondents have taken training on the procedures and other issues related the system before started to use. in other word that most respondent have not took adequate training on the usage of tax register machine and advantage of the system. This can possibly create difference in knowledge about system among the taxpayers and created great difference of motivation towards paying expected amount as revenue to the town tax authority. It is also the condition that made most taxpayers to use their duty forceful than based on interest and understanding the ever advantage of collecting VAT by using new technology and increasing revenue for country development at large. This showed there was gap among taxpayers on their level of awareness.

There is additional cost incurred by business organization in completion of tax activities by using ETRs. The main sources of additional costs identified were: cost related to salary of machine operator, the cost of Initial machine purchase, installation of machine, ETRs maintenance cost, purchase of stationeries and cost of annual machine checkup.

The use of ETRs has significantly improved the collection of value added tax and has increased government income. When compared to pre implementation of ETRs there is great difference in revenue of Government in the town, this indicated that income from revenue of the town and country at large might increase greater than this, if there is no challenges regard to implementation of ETRs and if all VAT registered tax payers use ETRs.

The maintenance service provided by the ETRs supplier to ETRs users was not adequate and satisfactory. This could force tax payers to make sales without using ETRs that may expose them to fraud and may result in opening door for tax evasion.

\section{Recommendations}

Depending on conclusion from findings of Electronics tax register system implementation challenges, the following points were recommended by the researcher.

It was found that Electronics tax register system implementation at study area lacked pre-information and survey in advance. Hence, there should be government tax officials' effort to create wide awareness creation on ETRs implementation procedures and its advantages both individually and collectively through mass media, and taxpayer based peer learning and reflecting the advantage of using the system for tax payment.

Enforcing to use the system without telling about its advantages has no sustainability effort to increase the income of one area and of country at large and there required and mandatory to mobilize need and interest based means of tax payment among all.

There are businesses Organization that are not yet using the system, which should have to use according to their capital. Government should enforce that all VAT registered tax payers those who are eligible for using the system to use the system and increase supplier of the machine in order to reach the machine to all potential VAT payer.

This will ensure that all businesses in the category receive equal treatment from the government and establish effectiveness, accuracy of the assessment, establishing discipline and non-corrupt personality of the ETRs implementing workers. 
In order to fully realize the fruits and benefits of ETRs: ERCA should introduce ETRs that are not expensive, cost to be paid in installments bases or loan should be facilitated; ETRs should be Compatible with computers in business premises; maintenance of machine should be free since they benefit the government in revenue collection and ERCA should introduce ETRs that save power for long period of time.

To improve or solve machine maintenance problem ,ERCA should give training for its employee's continuously and establish one center which make maintenance service instead of waiting supplier and make inspection regularly in order to check whether supplier of ETRs response to user and satisfies according to prescribed under regulation. The researcher final recommended other researcher to conduct further study on same topic or related particularly on the factors that influence utilization ETRs.

\section{Reference}

Amin Abdella and John Clifford (2010). The Impact of Tax Reform on Private Sector Development Addis Ababa Chamber of Commerce and Sectoral Associations. Addis Ababa, Ethiopia

Aminur Rahman (2009). P 1-5, Tackling Corruption through Tax Administration Reform page 1 A report to the G-20, (2011). Development working group by the IMF, OECD, UN and World Bank: Support development of more effective tax system

BekureHerouy 2004; The VAT Regime under Ethiopian Law with special Emphasis on TaxExemption: The Ethiopian and International Experience

Black's Law Dictionary (1979). 5th ed. p. 1307.

BuzalemBelete, (2015).Practices and challenges of Value Added tax Implementation in Ethiopia post January 2003 assessment

Cnossen, Sijbren(2006). Role and Rationale of Excise Taxation. In Excise Tax Policy and Administration in Southern African Countries, Eds. SijbrenCnossen, 1-20. Pretoria: University of South Africa

Christophe Grandcolas(2006).International the Occasional Failure in Vat Implementation: Lessons for the Pacific

DiamantaSkenderi(2012). Annual Revenues from Kosovo's Value Added Tax

Eric Toder, Jim Nunns, and Joseph Rosenberg (2012). p 4-6Implications of Different Bases for a VAT

FaridTadros(2009).Investment climate in practice, introducing the Value-Added Tax Considerations for implementation

Fuest,C.,\&Riedel,N. (2009). Tax evasion, tax avoidance and tax expenditures in developing countries: A review of the literature, Oxford University for Business Taxation Federal NegaritGazeta Proclamation No. 285/2002 Value Added Tax

Graham Glenday(2005). p 105-112,Assessment of the Current State of VAT Implementation in SADC Member States, Duke Center for International Development ,Duke University

GIZ (2010). Addressing tax evasion and tax avoidance in developing countries

Guillermo Jimenez, Niall Mac antSionnaigh, and Anton Kamenov,2013, USAID’S Leadership in public Finance Management information Technology for Tax Administration

Hamdu Kediri,ZinashDegife 2014, Challenges of Electronics Tax Register machine (ETRs) to Business and its impact in improving Tax Revenue (published, July 2014. Vol. 5,)

Hailemariam, Mamo(2011).Implementation of value added tax and its Related problems in Ethiopia" (The Case of ERCA)

Jane MuthoniWeru, Mary WanjiraKamaara, Alice NjeriWeru 2013, Impact of strategic change: Introduction of Electronic Tax Register for Enhancement of tax collection at Kenya Revenue Lammesaayalaa, (2012). Training manual prepared on utilization cash register machine, Oromia revenue authority

Lumumba Omweri Martin (2010). The Effectiveness of ELECTRONIC TAX REGISTERS in Processing of VALUE ADDED TAX ReturnsAIBUMA Publishing Vol. 1

Peter MutisyaMativo, WillyMuturi, AndrewNyang'au, (2015). Factors affecting utilization of Electronics tax Register (ETRs) in small and medium enterprise, in Kenya: A case of Nairobi CBD

Ross, Michael, L. (2007-01-27). Does Taxation Lead to Representation?". UCLA Department of Political Science. http://www.polisci.ucla.edu/faculty/ross/taxrep.pdf. Retrieved 2007-09-30.(accessed February 24, 2012)

Schenk, A and Oldman, O 2001. Value Added Tax: A comparative Approach in theory \& practice. New York: Transition publishers Inc.

Simon Tareke\&YibrahHagos(2013)., p 5Problems and Prospects of Value-Added Tax (VAT) Implementation (case in Tigrai Regional State), Research journalist Journal of Accounting

United States Government Accountability Office (GAO) 2008, p 6-9, report to congressional Requester's valueadded taxes lessons learned from other countries on compliance risks, Administrativecosts, compliance burden, and transition

WollelaAbehodieYesegat(2008). Value Added Tax Administration in Ethiopia: A Reflection of Problems 
www.itdweb.org2010; Tax Dialogue Revenue Administration In Sub- Saharan Africa P 6-9

YalemtesfaTaye, 2011,the impact of Electronic Tax Register on Value Added Tax: on the case of,Addis Ababa City. P 30-32

TemtimeDebere,(2014),Business Taxpayers' Satisfaction with the Tax System in Addis Ababa, Ethiopia

Abdu Muhammed\&ZemenuTesafa,(2015), The Impact of Electronic Tax Register Machines on VATCompliance in Ethiopia, the Case of Bahir Dar City.

Research Journal of Finance and Accounting,Vol.6, No.13, 2015

IMF Country Report No. 11/138. (2011), Advancing Tax Reform and the Taxation of Natural Resources

JAYAKUMAR., Ph.D. (2010)A STUDY ON IMPACT OF VALUE ADDED TAX (VAT) IMPLEMENTATION IN INDIA

Thomson Reuters 2012 .China VAT reform: achieving a successful transition to VAT

\section{Tax Regulations}

Council of Ministers Regulation No. 139/2007 Regulation for the Obligatory Use of Sales Register Machine

\section{Tax Laws}

Proclamation No 286/94 Direct and Indirect Tax Proclamation

Proclamation No. 227/2001 Amended by No. 286/2002 Income Tax Proclamation

Proclamation No. 227/2001 Withhold Tax Proclamation

Proclamation No.285/2002 VAT Proclamation

Proclamation No. 228/2001 Amended by No. 307/2002 Excise Tax Proclamation

Proclamation No. 08/2002 Turnover Tax

Proclamation No. 286/94 Tax ID Number and Finger Print 